\author{
Original Article
}

\title{
Identification of Maxillofacial Problems in Extraoral Photographs by Panel Members: A Pilot Study
}

\author{
Yağmur Kılıçaslan', Türkan Sezen Erhamza' (D), Ferabi Erhan Özdiler²
}

'Department of Orthodontics, Kirıkkale University School of Dentistry, Krrıkale, Turkey

${ }^{2}$ Department of Orthodontics, Ankara University School of Dentistry, Ankara, Turkey

Cite this article as: Kilıçaslan Y, Sezen Erhamza T, Özdiler FE. Evaluation of the Photographs Used in Determining Maxillofacial Problems by Panel Members: A Pilot Study. Turk J Orthod 2019; 32(1): 41-6.

\section{ABSTRACT}

Objective: The aim of this pilot study was to evaluate the effectiveness of the profile and frontal photographs in determining sagittal maxillofacial problems by the panel members created from different professional groups.

Methods: Frontal and profile photographs of four individuals with skeletal Class I, Class II Division 1, Class II Division 2, and Class III malocclusion were assessed by panel members. A total of 42 panel members from 7 different professions participated in the study. Panel members were asked to choose one of the frontal or profile photographs to be used in determining the maxillofacial problem. Mann-Whitney U test, Kruskal-Wallis test, and Fisher's exact test were applied to evaluate the difference between the panelists.

Results: Of the 42 panel members, 16\% selected frontal photographs, and 84\% selected profile photographs. There were no statistically significant differences between seven panels with regard to photography selection $(p>0.05)$. When all panel members were compared with regard to gender, $17.9 \%$ of the frontal photographs and $82.1 \%$ of the profile photographs were selected by females, whereas $15.4 \%$ of the frontal photographs and $84.6 \%$ of the profile photographs were chosen by males. There was no statistically significant difference between males and females ( $p>0.05$ ).

Conclusion: It was found that the profile photograph was more preferred and informative in determining the sagittal maxillofacial problem.

Keywords: Behavioral science, face, layout, malocclusion, perception, photography

\section{INTRODUCTION}

The most important factors affecting the facial appearance are the sagittal, vertical, and transversal relationships of the maxilla and mandible to the cranial base and/or to each other and the reflection of these skeletal structures to the soft tissue. In the past, orthodontists primarily aimed to align the teeth; today, they also intend to achieve a balanced facial aesthetics (1).

Consequently, pretreatment and posttreatment photographs, soft tissue appearance, and facial aesthetics have been progressively gaining importance. Achieving optimal facial aesthetics is primarily determined by the aesthetic perceptions and evaluations of the individual patients rather than by the ideal cephalometric values targeted by orthodontic treatment. Therefore, to fulfill the needs of patients, it is important to anticipate their expectations and to discuss their aesthetic perceptions, orientation, and motivation $(2,3)$. Owing to the reasons mentioned above, panel studies have been used to collect ideas about and to compare the aesthetic perceptions of dentists, dental specialists, and professionals from other related fields, such as maxillofacial surgeons and plastic reconstructive and aesthetic surgeons. Panels consist of individuals who evaluate the documentation, such as photographs and X-ray images, based on their own point of view and aesthetic perception (4). Variables, such as age, gender, and profession of the panel members, may affect their preferences. Previous studies have evaluated various anomalies (5), the pre-intervention and post-intervention

Address for Correspondence: Yağmur Kılıçaslan, Department of Orthodontics, Kırıkkale University School of Dentistry, Received: April 24,2018 


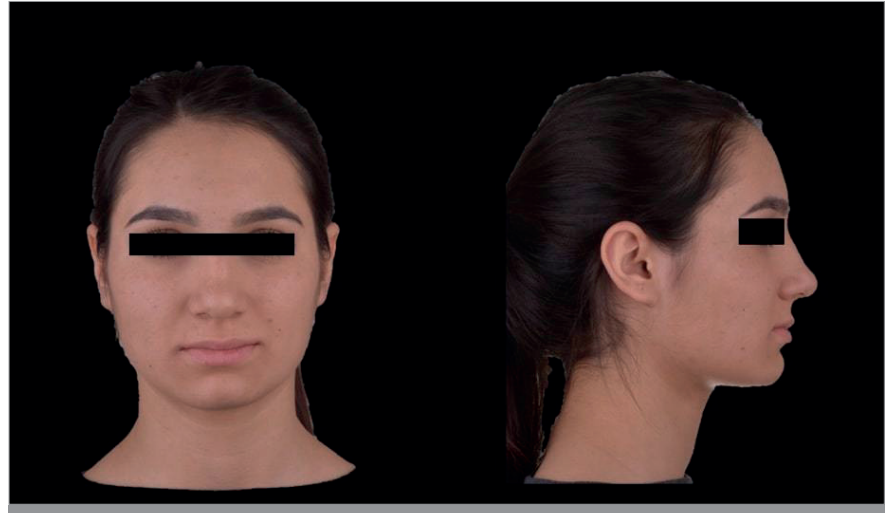

Figure 1. Patient with Class I malocclusion

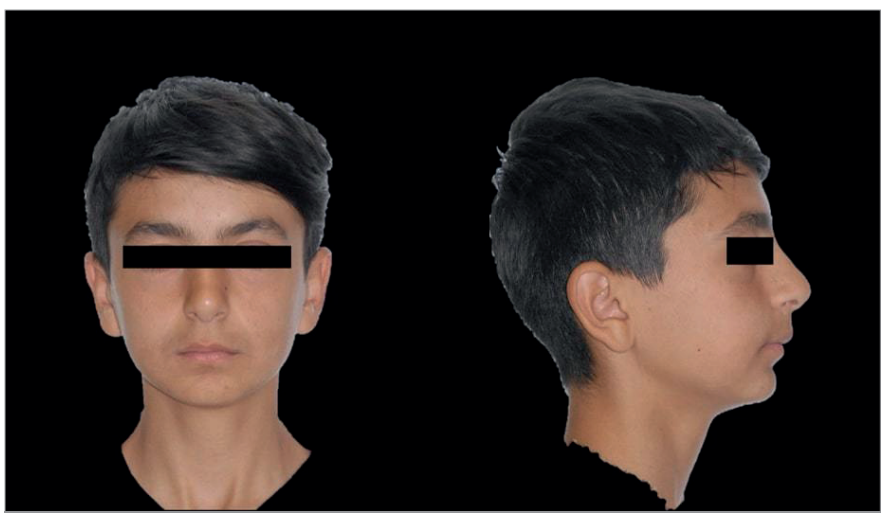

Figure 2. Patient with Class II Division 1 malocclusion

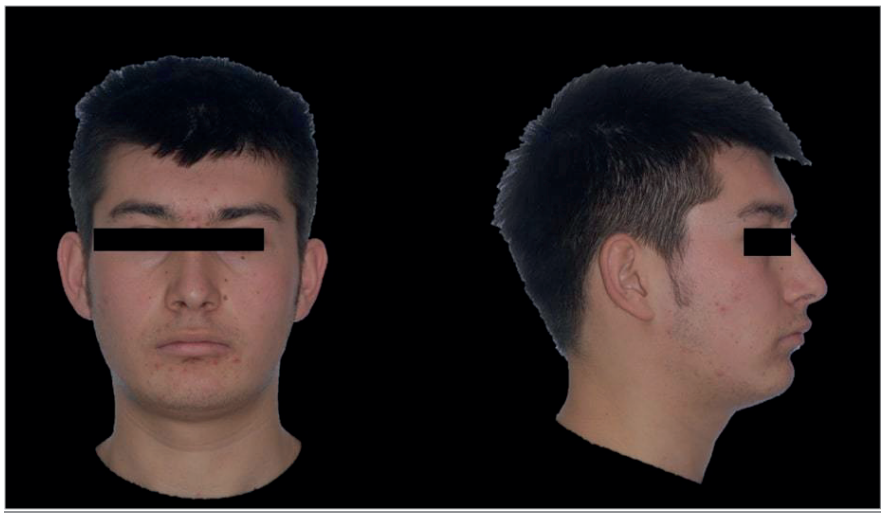

Figure 3. Patient with Class II Division 2 malocclusion

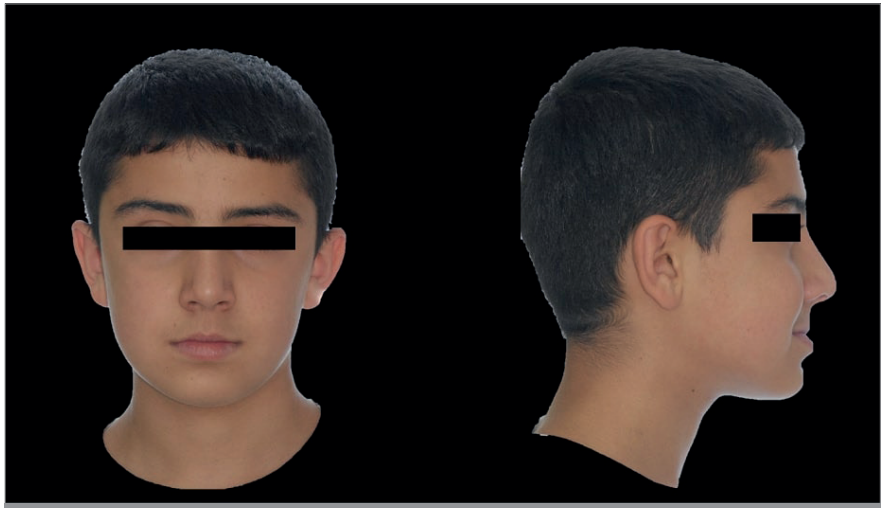

Figure 4. Patient with Class III malocclusion results of extraction and non-extraction treatments, orthognathic surgeries (6-9), and smile aesthetics $(10,11)$.

To evaluate aesthetics, lateral cephalograms, profile silhouette images, frontal photographs, profile photographs, and 3/4 photographs are frequently used. Frontal photographs are usually used to determine facial proportions, asymmetries, and transversal evaluations (12). On the other hand, profile photographs are frequently used to assess the anteroposterior position of the maxilla and mandible, the soft tissue profile, and the vertical dimensions $(12,13)$. One panel study reported that simultaneous display of both profile and frontal photographs is more advantageous than displaying only one type of photographs (5). However, to the best of our knowledge, no study has reported on which types of photographs can be more useful in understanding sagittal maxillofacial problems.

The aim of the present study was to determine whether frontal or profile photographs would be more effective for evaluating sagittal maxillofacial problems. The null hypothesis assumed that there was no difference between the selection of photographs of various groups consisting of professionals with different ages.

\section{METHODS}

The samples were selected from the registry of Kırıkkale University, Faculty of Dentistry, Department of Orthodontics. The study was approved by the ethics committee of clinical investigations of Kırıkkale University.

\section{Sample Selection}

The frontal and profile photographs of four patients with skeletal Class I, Class II Division 1, Class II Division 2, and Class III malocclusion (according to the ANB angle) were used (14). The photographs were captured using a digital camera (Nikon D7100; Nikon Corporation, Tokyo, Japan). Inclusion criteria were photographs being standardized (similar light, Frankfurt horizontal plane parallel to the horizontal, and lips relaxed); no asymmetry, craniofacial anomaly, and syndrome; no previous orthodontic treatment, maxillofacial, or plastic surgery; no trauma related to the face and neck; no mustache, beard, acne, striking hairpin, jewelry, makeup, glasses, and scarf (Figures 1, 2, 3, 4).

The lateral cephalometric radiographs were analyzed using VistaDent 2.1 AT (GAC International Inc., Bohemia, NY, USA) software program. A four-slide presentation (Microsoft Office 2010, PowerPoint, Seattle, WA, USA) was prepared for evaluation of the samples. The frontal and profile photographs of Class I (17-yearold female, ANB: $3^{\circ}$, overjet: $2.5 \mathrm{~mm}$ ), Class II Division 1 (14-yearold male, ANB: $6.3^{\circ}$, overjet: $7.3 \mathrm{~mm}$ ), Class II Division 2 (16-yearold female, ANB: $6.5^{\circ}$, overjet: $4 \mathrm{~mm}$ ), and Class III (14-year-old male, ANB: $-2^{\circ}$, overjet: $-1.5 \mathrm{~mm}$ ) patients with malocclusion were presented (Table 1). In the photos, the patient's lips were relaxed, and their eyes were closed with black stripes. The presentation included frontal and profile photographs of each patient on a single slide, similar to the study by Philips et al. (5). Smile photographs were not included to avoid affecting panel members by any dental anomaly; thus, photographs with lips closed were preferred (15). 


\section{Panel Formation}

Seven panels were assembled for selection of the photographs to be used in the determination of the maxillofacial problem. Panel members included first-year dental students, fifth-year dental students, orthodontists, oral and maxillofacial surgeons, plastic reconstructive and aesthetic surgeons, dentists, and parents of orthodontic patients. A total of 42 panelists were involved in the study, and each panel constituted of 6 members.

The age of the panel members was between 19 and 45 years. The median ages of the panel members were 20.5 years for first-year dental students, 23 years for fifth-year dental students, 29 years for orthodontists, 27.5 years for oral and maxillofacial surgeons, 30 years for plastic reconstructive and aesthetic surgeons, 41.5 years for dentists, and 40 years for the parents of the individuals (Table 2).

Following the question "which photographs should be used in determining the maxillofacial problem?," each slide was displayed for $5 \mathrm{~s}$, and members were asked to choose one of the frontal or profile photographs.

\begin{tabular}{|lcccc|}
\hline \multicolumn{5}{c|}{ Table 1. Cephalometric values of four patients } \\
\hline & Class I & $\begin{array}{c}\text { Class II } \\
\text { div 1 }\end{array}$ & $\begin{array}{c}\text { Class II } \\
\text { div 2 }\end{array}$ & Class III \\
\hline ANB $\left(^{\circ}\right)$ & $3^{\circ}$ & $6.3^{\circ}$ & $6.5^{\circ}$ & $-2^{\circ}$ \\
Wits $(\mathrm{mm})$ & $0 \mathrm{~mm}$ & $6 \mathrm{~mm}$ & $6 \mathrm{~mm}$ & $-3 \mathrm{~mm}$ \\
FMA $\left(^{\circ}\right)$ & $20^{\circ}$ & $21^{\circ}$ & $21^{\circ}$ & $23^{\circ}$ \\
SN-GoGn $\left(^{\circ}\right)$ & $28.7^{\circ}$ & $31.1^{\circ}$ & $28^{\circ}$ & $34^{\circ}$ \\
SN-OcP $\left(^{\circ}\right)$ & $15.7^{\circ}$ & $23.9^{\circ}$ & $18.3^{\circ}$ & $15^{\circ}$ \\
Mx1-SN $\left(^{\circ}\right)$ & $103.4^{\circ}$ & $109.6^{\circ}$ & $90.5^{\circ}$ & $98^{\circ}$ \\
U1-NA (mm) & $7 \mathrm{~mm}$ & $5 \mathrm{~mm}$ & $9 \mathrm{~mm}$ & $4 \mathrm{~mm}$ \\
U1-NA $\left(^{\circ}\right)$ & $25.3^{\circ}$ & $29.3^{\circ}$ & $10.2^{\circ}$ & $20^{\circ}$ \\
L1-NB (mm) & $4 \mathrm{~mm}$ & $3 \mathrm{~mm}$ & $5 \mathrm{~mm}$ & $5 \mathrm{~mm}$ \\
L1-NB $\left(^{\circ}\right)$ & $24.4^{\circ}$ & $27.1^{\circ}$ & $22.5^{\circ}$ & $23^{\circ}$ \\
IMPA $\left(^{\circ}\right)$ & $100^{\circ}$ & $105^{\circ}$ & $100^{\circ}$ & $91^{\circ}$ \\
Overjet (mm) & $2.5 \mathrm{~mm}$ & $7.3 \mathrm{~mm}$ & $4 \mathrm{~mm}$ & $-1.5 \mathrm{~mm}$ \\
Overbite (mm) & $2.5 \mathrm{~mm}$ & $4 \mathrm{~mm}$ & $6.5 \mathrm{~mm}$ & $3.5 \mathrm{~mm}$ \\
Lower lip E-line (mm) & $-6 \mathrm{~mm}$ & $0 \mathrm{~mm}$ & $-1 \mathrm{~mm}$ & $-6 \mathrm{~mm}$ \\
Upper lip E-line (mm) & $-1 \mathrm{~mm}$ & $0 \mathrm{~mm}$ & $-2 \mathrm{~mm}$ & $1 \mathrm{~mm}$ \\
\hline
\end{tabular}

\section{Statistical Analysis}

Statistical analysis was performed using the Statistical Package for Social Sciences version 15.0 (SPSS Inc.; Chicago, IL, USA) package program. Numerical variables were presented as median (minimum-maximum), and categorical variables were presented as frequency (percentage). Differences among the groups were determined by Mann-Whitney $U$ test, Kruskal-Wallis test, and chisquare and Fisher's exact tests. A p value $<0.05$ was considered statistically significant.

\section{RESULTS}

As the answer of "which photographs should be used in determining the maxillofacial problem?" question, $16 \%$ of the panel members chose frontal photographs, and $84 \%$ chose profile photographs. No statistically significant difference was found among the decisions of seven different panels with regard to photography selection (Table 3).

In evaluating the photograph of the patient with Class I malocclusion (slide 1), $31 \%$ of the panel members chose frontal, and 69\% chose profile photograph. For Class II Division 1 malocclusion patient (slide 2), $4.8 \%$ of the panel members selected frontal, and $95.2 \%$ selected profile photographs. For Class II Division 2 malocclusion (slide 3), 14.3\% of the panel members chose frontal, and $85.7 \%$ chose profile photograph. For Class III malocclusion patient (slide 4 ), $16.7 \%$ of the panel members chose frontal, and $83.3 \%$ chose profile photograph (Table 2).

When the decisions of the panel members were compared with regard to their gender, $17.9 \%$ of the females selected frontal, and $82.1 \%$ selected profile photographs, whereas $15.4 \%$ of the males chose frontal, and $84.6 \%$ chose profile photographs. No statistically significant difference was found between the decisions of males and females.

Orthodontists preferred profile photographs for all malocclusions, and dentists preferred profile photographs for Class 2 and 3 malocclusions.

Table 2. Demographic data of panelists

\begin{tabular}{|c|c|c|c|c|c|c|}
\hline Panel & $\mathbf{n}$ & Females & Males & \multicolumn{3}{|c|}{ Average age } \\
\hline First-year dental students & 6 & 3 & 3 & 20.5 & 19 & 21 \\
\hline Fifth-year dental students & 6 & 3 & 3 & 23 & 23 & 25 \\
\hline Orthodontists & 6 & 3 & 3 & 29 & 27 & 34 \\
\hline Oral surgeons & 6 & 3 & 3 & 27.5 & 26 & 31 \\
\hline Plastic surgeons & 6 & 3 & 3 & 30 & 27 & 40 \\
\hline Parents of orthodontic patient & 6 & 3 & 3 & 40 & 36 & 50 \\
\hline
\end{tabular}




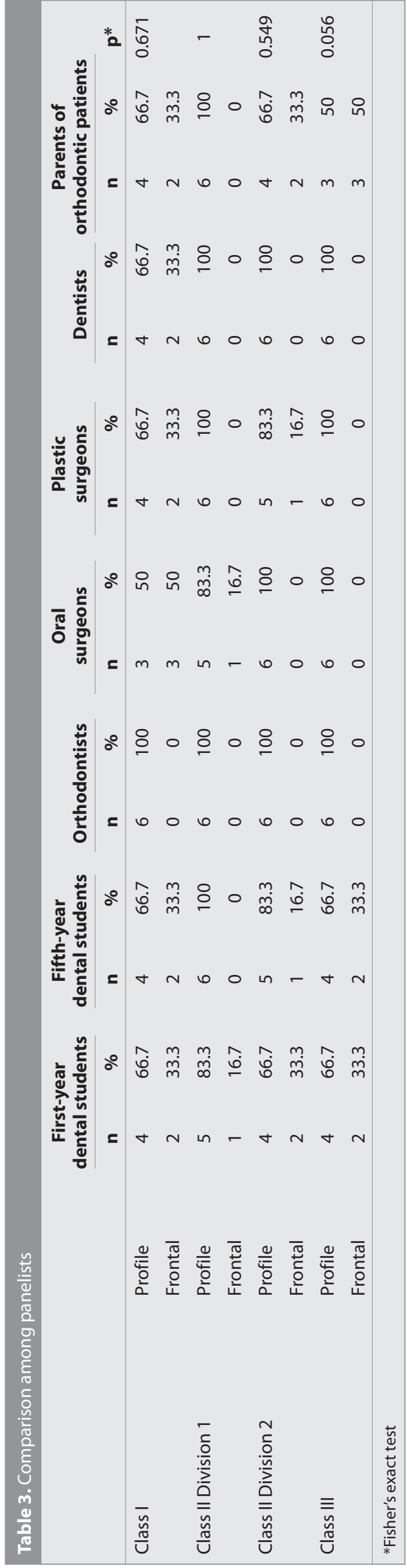

\section{DISCUSSION}

Previous studies investigated different anomalies (5), pre- and posttreatment results of extraction and non-extraction orthodontic treatments, and orthognathic surgeries (6-9). In other studies, patients treated with orthognathic surgery and growth modification pre- and posttreatment results of functional appliance treatment $(16)$ and smile aesthetics $(10,11)$ were evaluated using digital photographs. The investigations usually involved scoring of facial attractiveness and smile aesthetic using the visual analog scale. However, our pilot study aimed to question whether frontal or profile facial photographs would be more effective in the evaluation of sagittal maxillofacial problems based on the point of view of professionals from different fields.

Aesthetic evaluations are generally known to be based on profile and frontal photographs, as well as profile silhouette images obtained from cephalograms $(5-11,15,16)$. Recently, three-dimensional images and video recordings have also been used; however, no statistically significant difference between photographs and video images has been reported in the literature (17, 18). Therefore, frontal and profile photographs were used in our study.

Some studies emphasized that the use of cephalograms and profile silhouettes would provide more accurate results than that of photographs because variables, such as skin color and texture, hair color and style, and facial expressions, could affect the specialists' decisions $(19,20)$. However, the face cannot be fully examined with these methods, particularly during frontal evaluation $(19,21)$. Therefore, frontal view evaluation was used in our study instead of silhouette images and cephalograms. To prevent the manipulation of the decisions of the members, mustache, beard, acne, herpes, striking hairpins, scarves, jewelry, and makeup were not present in the photographs of the patients included in the sample.

In some studies on aesthetic evaluations, panel members have been reported to be affected by their own appearance during the decision-making process $(22,23)$. The assessments of individuals dissatisfied with their own facial profile could result in more negative scores (24). Thus, it is necessary to include a larger number of panelists to minimize the impact that the subjectivity of the members' reflections has on their decisions in relation to the study results (16). However, it has also been reported that contrary to the perception that a fewer number of members would lead to less reliable results, too many panel members would result in considerable time loss (25). Howells and Shaw (26) stated that the reliability of the two-people panel is acceptable, but it would be better to increase the number of panel members. Thus, our study included a total of 42 individuals from 7 different occupational groups.

In the current body of literature, studies evaluating facial attractiveness reported that frontal photographs were more important than profile photographs $(7,8)$; however, in the assessment 
of skeletofacial morphology, it was proposed that lateral images, such as cephalometric radiographs, provide more information than frontal images $(14,27)$. These results might explain the high preference of profile photos in our study because the panel members were asked to select photographs to determine the sagittal maxillofacial problem rather than make an aesthetic evaluation.

Matoula and Pancherz (28) reported that when examining the effect of lateral skeletal morphology, differences in lateral skeletal morphology are less noticeable in the frontal images. Therefore, since profile observation in profile photographs of Class II Division 1, Class II Division 2, and Class III patients is more intense and striking, panel members might have preferred profile photographs rather than frontal photographs to evaluate these anomalies. The presence of an orthognathic profile in Class I anomalies could explain the close decision ratios of frontal and profile photographs in comparison with other anomalies. Furthermore, the fact that orthodontists only chose profile photographs for all anomalies could be explained by the use of cephalometric radiographs for lateral assessments in determining maxillofacial problems during orthodontic training.

Different malocclusions have been evaluated in the aesthetic perception studies $(5-9,11,15,29)$. In our study, the photographs of individuals with Class I, Class II Division 1, Class II Division 2, and Class III anomalies were used to assess whether changes in anomalies could be seen in the photographs selected by panel members when determining maxillofacial problems.

\section{CONCLUSION}

No difference was found in the perceptions of different occupational groups, different ages, and different genders in our study which looked for the answer of the question "Should I use frontal or profile photographs in determining sagittal maxillofacial problems?". Our findings have shown that profile photographs would be more preferable when evaluating maxillofacial problems.

Ethics Committee Approval: Ethics committee approval was received for this study from the Ethics Committee of Kırıkkale University.

Informed Consent: Written informed consent was obtained from the patients who participated in this study.

Peer-review: Externally peer-reviewed.

Author Contributions: Concept - Y.K., T.S.E., F.E.Ö.; Design - Y.K., T.S.E., F.E.Ö.; Supervision - Y.K., T.S.E., F.E.Ö.; Data Collection and/or Processing - Y.K., T.S.E., F.E.Ö.; Analysis and/or Interpretation - Y.K., T.S.E., F.E.Ö.; Literature Search - Y.K., T.S.E., F.E.Ö.; Writing Manuscript - Y.K., T.S.E., F.E.Ö.; Critical Review - Y.K., T.S.E., F.E.Ö.

Conflict of Interest: The authors have no conflict of interest to declare.

Financial Disclosure: The authors declared that this study has received no financial support.

\section{REFERENCES}

1. Zylinski CG, Nanda RS, Kapila S. Analysis of soft tissue facial profile in white males. Am J Orthod Dentofacial Orthop 1992; 101: 514-8. [CrossRef]

2. Sarver DM. Esthetic Orthodontics and Orthognathic Surgery. 1st edition ed. St Louis Missouri: Mosby; 1998.

3. Aksakallı S. Ortodontik tedavi görmüş bireylerle ebeveynlerinin yüz estetiğinin kıyaslanması: Selçuk Üniversitesi Sağlık Bilimleri Enstitüsü; 2013.

4. Edler R, Agarwal P, Wertheim D, Greenhill D. The use of anthropometric proportion indices in the measurement of facial attractiveness. Eur J Orthod 2006; 28: 274-81. [CrossRef]

5. Phillips C, Tulloch C, Dann C. Rating of facial attractiveness. Community Dent Oral Epidemiol 1992; 20: 214-20. [CrossRef]

6. Bowman SJ, Johnston Jr LE. The esthetic impact of extraction and nonextraction treatments on Caucasian patients. Angle Orthod 2000; 70: 3-10.

7. Kerr W, O'donnell J. Panel perception of facial attractiveness. $\mathrm{Br} \mathrm{J}$ Orthod 1990; 17: 299-304. [CrossRef]

8. Vargo J, Gladwin M, Ngan P. Association between ratings of facial attractivess and patients' motivation for orthognathic surgery. Orthod Craniofac Res 2003; 6: 63-71. [CrossRef]

9. Ming T, Sandham A, Soh J, Hwee B. Outcome of orthognathic surgery in Chinese patients. 2007.

10. Moore T, Southard KA, Casko JS, Qian F, Southard TE. Buccal corridors and smile esthetics. Am J Orthod Dentofacial Orthop 2005; 127: 208-13. [CrossRef]

11. Işıksal E, Hazar S, Akyalçın S. Smile esthetics: perception and comparison of treated and untreated smiles. Am J Orthod Dentofacial Orthop 2006; 129: 8-16. [CrossRef]

12. Graber LW, Vanarsdall Jr RL, Vig KW, Huang GJ. Orthodontics: current principles and techniques: Elsevier Health Sciences; 2016.

13. Proffit WR, Fields Jr HW, Sarver DM. Contemporary orthodontics: Elsevier Health Sciences; 2014

14. Steiner CC. Cephalometrics for you and me. Am J Orthod 1953; 39: 729-55. [CrossRef]

15. Shell TL, Woods MG. Perception of facial esthetics: a comparison of similar class II cases treated with attempted growth modification or later orthognathic surgery. Angle Orthod 2003; 73: 365-73.

16. O'Neill K, Harkness M, Knight R. Ratings of profile attractiveness after functional appliance treatment. Am J Orthod Dentofacial Orthop 2000; 118: 371-6. [CrossRef]

17. Ferrario VF, Sforza C, Poggio CE, Schmitz JH, Colombo A. Soft tissue facial morphology related to headform: a three-dimensional quantitative analysis in childhood. J Craniofac Genet Dev Biol Suppl 1996; 17: 86-95.

18. Van der Geld P, Oosterveld P, Van Heck G, Kuijpers-Jagtman AM. Smile attractiveness: self-perception and influence on personality. Angle Orthod 2007; 77: 759-65. [CrossRef]

19. Barrer JG, Ghafari J. Silhouette profiles in the assessment of facial esthetics: a comparison of cases treated with various orthodontic appliances. AmericanJ Orthod 1985; 87: 385-91. [CrossRef]

20. Cox $\mathrm{NH}$, Van der Linden FP. Facial harmony. American J Orthod 1971; 60: 175-83. [CrossRef]

21. Mackley RJ. An evaluation of smiles before and after orthodontic treatment. Angle Orthod 1993; 63: 183-9.

22. Hershon LE, Giddon DB. Determinants of facial profile self-perception. American J Orthod 1980; 78: 279-95. [CrossRef]

23. Klima RJ, Wittemann JK, Mclver JE. Body image, self-concept, and the orthodontic patient. American J Orthod 1979; 75: 507-16. [CrossRef] 
24. Baldwin DC. Appearance and aesthetics in oral health. Community Dent Oral Epidemiol 1980; 8: 244-56. [CrossRef]

25. Kiekens RM, van't Hof MA, Straatman H, Kuijpers-Jagtman AM, Maltha JC. Influence of panel composition on aesthetic evaluation of adolescent faces. Eur J Orthod 2007; 29: 95-9. [CrossRef]

26. Howells DJ, Shaw WC. The validity and reliability of ratings of dental and facial attractiveness for epidemiologic use. American J ORthod 1985; 88: 402-8. [CrossRef]
27. Downs WB. Analysis of the dentofacial profile. Angle Orthod 1956; 26: 191-212.

28. Matoula S, Pancherz $\mathrm{H}$. Skeletofacial morphology of attractive and nonattractive faces. Angle Orthod 2006; 76: 204-10.

29. Kiekens RM, Maltha JC, van't Hof MA, Straatman H, Kuijpers-Jagtman AM. Panel perception of change in facial aesthetics following orthodontic treatment in adolescents. Eur J Orthod 2008; 30: 141-6. [CrossRef] 